\title{
TEACHERS QUESTIONS: A SURVEY OF ENGLISH TEACHERS' QUESTIONING TECHNIQUES
}

\author{
Patricia Glinton, Humanities Division, College \\ of the Bahamas. \\ Irene King, R. M. Bailey Senior High School. \\ Jonathan Young, Teacher Education Division, College \\ of the Bahamas.
}

\section{INTRODUCTION}

Classroom teaching has formed the core of educational systems for generations and is likely to do so for years to come; change to another format would require a considerable reorganization in the political and economic framework of any society which sought such innovation and, indeed, a radical modification of the convictions of ordinary citizens who are often not aware that such alternatives exist.

Central to classroom teaching is the teacher/student interaction known as the 'recitation', a process described by Gage and Berliner ${ }^{2}$ in this fashion:

the continually repeated chain of events in which:

1. The teacher provides structuring, briefly formulating the topic or issue to be discussed; then,

2. The teacher solicits a response or asks a question of one or more students; then,

3. A student responds or answers the question; and,

4. The teacher reacts to the student's answer.

One may infer from the foregoing that teacher talk, rightly or wrongly, dominates classroom procedure. This inference has substantial support in the literature. For example, Floyd ${ }^{3}$ recorded thirty-one hours of class time in elementary schools, and a subsequent analysis of this material credited the teacher with 71 per cent of all words spoken.
While the figure is in itself remarkable, it is even more significant that most of the words spoken by teachers are emitted in the form of questions. In his review of studies which consider the role of questions in teaching. $\mathrm{GaIl}^{4}$ reports a figure as high as 150 questions per hour for elementary school teachers, while Guilford 5 notes that questioning represents as much as 80 per cent of teacher talk.

In any fieldin which there are few well developed theories to guide behaviour -- as is the case with instruction -- research of any behaviour is likely to be useful, but a phenomenon which manifests itself with such notable frequency as teacher questioning demands research. This premise is particularly applicable to the Bahamian context as there has been little empirical research carried out of any kind. It is evident that classroom teaching is the basic procedure in Bahamian education, but many of the teacher behaviour variables that are involved, such as questioning, have yet to be assessed.

\section{Questions and Learning Theory}

Within educational theory, the work of two learning theories is particularly pertinent to the issue of questioning techniques. Skinner's Behaviour Modification Theory, first of al1, suggests how learning may take place with teacher questioning -- the question serving as the descriminative stimulus for the response of the student which is reinforced by the reaction of the teacher. Since the teacher controls the stimulus and the reinforcer she should be able to induce the desired response. Since questioning initiates some form of cognitive processing in the 
respondant, Piaget's work on cognitive development also has implications for this technique. In order to process the question in a satisfactory manner, the student would need to have reached a congruent level, of cognitive development.

\section{The Assessment of Questions}

Questions are normally assessed in terms of the cognitive processes thought necessary for the production of a response. The current practice in research is to place the questions into categories listed by one or more of the taxonomies of educational objectives, Bloom's Taxonomy being the most representative of that class.

In formulating their questions, teachers generally intend to fulfill purposes which are consistent with the range of objectives set forth in the taxonomies; but, practice is often a pale shadow of desire. In other words, instructors state frequently as their objectives skills such as analysis and evaluation which are highly placed in most taxonomies and which are believed to make the greatest demands on student reasoning; however, the questions that eventually reach the classroom elicit mainly recognition and recall skills, that require the least mental effort.

Guzak $^{6}$ placed teachers' questions into six categories: recognition, recall, translation, conjecture, explanation, and evaluation, and in his survey of teacher practice he classified 70.4 per cent of all questions as recognition or recall. Likewise, Bartolme found that as few as 4.9 per cent of questions formulated by primary teachers pertained to application and evaluation. It should be noted that since these cognitive processes seem to be hierarchical in nature recall is a necessary first step, yet it would also seem consistent with the general goals of education to cultivate the higher processes as we11. That teachers tend to ask questions which fall at the lower end of most listings of educational objectives is an important sonsideration since there is support in the literature for the view that the nature of the teachers' questions influence students' cognitive production. 8 In the research reported in this article, an attempt is made to look at the questioning techniques used by seven English Language teachers working in a single Government High School in New Providence.

\section{Methodology}

In carrying out this study each teacher was given a pre-selected passage and an advertising poster, and asked to teach: comprehension lesson based on these materials to four different classes usir both oral and written questions. 9 In a: twenty-eight lessons were observed, taus to classes from high, middle, and low streams in grades 10,11 , and 12 . The comprehension passage was as follows:

Fried foods have long been frowned on. Nevertheless the skillet is about the handiest and most useful piece of kitchen equipment. Lumberjacks and others engaged in active work, who need 4,000 calories a day eat about one-third of their food fried. Meats, eggs and French toast cooked in this manner are served in millions of home daily. It seems that people who eat these foods do not suffer more from indigestion than those who insist upon broiling, roasting, or boiling. Some years ago one of our most famous doctors investigated the digestability of fried potatoes. He found that the pan-fried variety was more easily broken down for digestion than French or deep fried potatoes. Even the deep fat variety, however, dissolved within the digestive tract more readily than boiled potatoes. Furthermore, he learned, by watching the progess of the contents of the stomach with $x$-rays, that fat actuall increased the rate of digestion.

\section{Findings}

Observation of twenty-eight comprehensio lesssons produced a total of 312 written and oral questions; which were classifie according to Bloom's Taxonomy, as shown in Table 1 . 
TABLE 1. Teachers' Questions by Type of Question

\begin{tabular}{|c|c|c|c|c|c|c|}
\hline & Recal1 & Application & Analysis & Synthesis & Evaluation & Total \\
\hline $\begin{array}{c}\text { Number } \\
\text { of } \\
\text { Questions }\end{array}$ & 155 & 54 & 60 & 28 & 15 & 312 \\
\hline
\end{tabular}

The table indicates an emphasis by teachers on lower order, factual questions, with twothirds of all questioning falling into either the recall or application category.

In order to examine whether or not teachers varied their questions with grade and stream, questions were analysed according to the grade and stream that they were addressed to (see Table 2a), and the significance of the differences found tested using the chisquare test of independence (see Table 2b).

While no significant differences were indicated (at the .05 level) in the types of questions asked at different grade levels, significant differences were indicated in questioning techniques used between different streams. A significant value of $x^{2}$ (at the .05 level of significance) was obtained for the type of questions asked in grades 10 and 12 , and for grades 10,11 and 12 combined, suggesting that higher order questions were asked more frequently stream students than of the lower stream students.

In addition the study sought to discover whether or not teachers differed in their questioning techniques between oral and written work. The data shown in Table 3 suggests that a higher proportion of lower order questions were posed orally than in written assignments.

\section{Discussion}

If teacher-directed questioning forms a major element of the teaching act, then it is important that educators look carefully at the types of questions that we are asking our students and the level of thought required in responding to then.

That the teachers surveyed in this study tended to ask mainly lower order questions -that elicited only a superficial understanding of the topic and which did little to guide or tax their students' thought -- is a finding consistent with other research done on the subject. Such questions are not without their value, for in the hierarchical structure of Bloom's Taxonomy it is the lower order knowledge and skills that provide the building blocks to higher order thought patterns. Yet to neglect the higher order questions is to avoid challenging students to "really think" or to stimulate them to creative, divergent thinking or problem solving.

Another important aspect of teacher questioning is its variation according to stream, a finding also supported elsewhere in the literature. The data suggests that teachers ask more higher order questions of the upper streams than the lower streams. If this is a true reflection of Bahamian classroom practice, then it is unfortunate; the students who are likely to be in greatest need of the least opportunity to develop them. Yet no teacher is likely to deny that constant practice is essential to the acquisition of a skill.

Perhaps teachers persist in asking mainly recall and recognition questions of low stream students because they feel that these students lack the mental apparatus to cope with anything beyond this level. This kind of thinking is without ground; Bahamian high school students are streamed according to performance on reading and mathematics tests and these are primarily measures of achievement rather than of innate mental ability. While they may be useful in assigning students to instructional groups, they lead to questionnable assumptions about potential for development which in turn leads to equally doubtful classroom practice. Not only do teachers label children dull but unwittingly set out to make the label 
Table 2(a) Questioning Technigue by Grade and Stream

\begin{tabular}{|c|c|c|c|c|c|c|c|}
\hline & \multicolumn{6}{|c|}{ TYPE OF QUES: IONS } & \multirow[b]{2}{*}{ TOTAL } \\
\hline & GRADE & RECAII & APPLICAIION & ANAIYSIS & SYNTHESIS & EVALUATION & \\
\hline \multirow{3}{*}{$\begin{array}{l}\text { HIGH } \\
\text { STREAM }\end{array}$} & 10 & $13(27 \%)$ & $7(14 \%)$ & $18(37 \%)$ & $6(12 \%)$ & $5(10 \%)$ & $49(100)$ \\
\hline & 11 & $10(37 \%)$ & $9(33 \%)$ & $4(15 \%)$ & $3(11 \%)$ & $1(4 \%)$ & $27(100)$ \\
\hline & 12 & $16(39 \%)$ & $7(17 \%)$ & $11(27 \%)$ & $2(5 \%)$ & $5(12 \%)$ & $41(100)$ \\
\hline \multirow{5}{*}{$\begin{array}{l}\text { MIDDLE } \\
\text { STREAM }\end{array}$} & TOTAL & $39(34 \%)$ & $23(20 \%)$ & $35(28 \%)$ & $11(9 \%)$ & $11(9 \%)$ & $317(100)$ \\
\hline & 10 & $41(52 \%)$ & $17(21 \%)$ & $13(16 \%)$ & $6(8 \%)$ & $2(3 \%)$ & $79(100)$ \\
\hline & 11 & $15(48 \%)$ & $5(16 \%)$ & $9(29 \%)$ & $2(7 \%)$ & 0 & $31(100)$ \\
\hline & 12 & - & - & - & - & - & - \\
\hline & TOTAL & $56(48 \%)$ & $22(20 \%)$ & $22(20 \%)$ & $8(7 \%)$ & $2(2 \%)$ & $110(100)$ \\
\hline \multirow[t]{2}{*}{ LOW } & 10 & $16(72 \%)$ & $I(5 \%)$ & $2(9 \%)$ & $I(5 \%)$ & $2(9 \%)$ & $22(100)$ \\
\hline & 11 & $24(65 \%)$ & $5(14 \%)$ & $2(5 \%)$ & $6(16 \%)$ & 0 & $37(100)$ \\
\hline \multirow[t]{2}{*}{ STREAM } & 12 & $20(76 \%)$ & $3(12 \%)$ & $1(4 \%)$ & $2(8 \%)$ & 0 & $26(100)$ \\
\hline & TOTAL & $60(7 \%)$ & $9(11 \%)$ & $5(6 \%)$ & $9(11 \%)$ & $2(2 \%)$ & $26(100)$ \\
\hline \multirow[t]{4}{*}{ TOTAL } & 10 & $70(46 \%)$ & $25(15 \%)$ & $33(22 \%)$ & $13(9 \%)$ & $9(6 \%)$ & $150(100)$ \\
\hline & 11 & $49(51 \%)$ & $19(20 \%)$ & $15(16 \%)$ & $11(12 \%)$ & $I(1 \%)$ & $95(100)$ \\
\hline & 12 & $36(54 \%)$ & & $12(18 \%)$ & & $5(7 \%)$ & $67(100)$ \\
\hline & TOTAL & $155(50 \%)$ & $54(15 \%)$ & $60(19 \%)$ & $28(9 \%)$ & $15(5 \%)$ & $312(100)$ \\
\hline
\end{tabular}


*For tests $1-3$ and 5 - 7 the data was collapsed toa $2 \times 3$ table of lower order and higher order questions.

TABLE 2(b) Chi-Square Test of Independence

\begin{tabular}{|c|c|c|c|c|c|}
\hline TEST & CHI-SQUARE & CELLS & $N$ & \multicolumn{2}{|c|}{ SIGNIFICANCE } \\
\hline $\begin{array}{l}\text { 1. High Stream, } \\
\text { Grade by } \\
\text { Question Type }\end{array}$ & 6.8 & $3 \times 2 *$ & 117 & $\mathrm{P}$ & .05 \\
\hline $\begin{array}{l}\text { 2. Middle Stream, } \\
\text { Grade by } \\
\text { Question Type }\end{array}$ & 0.86 & $2 \times 2$ & 110 & $P$ & .05 \\
\hline $\begin{array}{l}\text { 3. Low Stream, } \\
\text { Grade by } \\
\text { Question Type }\end{array}$ & 1.28 & $3 \times 2$ & 85 & $P$ & .05 \\
\hline $\begin{array}{l}\text { 4. Total, Grade } \\
\text { by Question } \\
\text { Type }\end{array}$ & 10.67 & $3 \times 5$ & 312 & $P$ & .05 \\
\hline $\begin{array}{l}\text { 5. Grade } 10, \\
\text { Stream by } \\
\text { Question Type }\end{array}$ & 15.9 & $3 \times 2$ & 150 & $P$ & .05 \\
\hline $\begin{array}{l}\text { 6. Grade } 11 \text {, } \\
\text { Stream by } \\
\text { Question Type }\end{array}$ & 1.6 & $3 x^{2}$ & 95 & P & .05 \\
\hline $\begin{array}{l}\text { 7. Grade } 12, \\
\text { Stream by } \\
\text { Question Type }\end{array}$ & 7.7 & $2 x^{2}$ & 67 & $\mathrm{P}$ & .05 \\
\hline $\begin{array}{l}\text { 8. Total Stream } \\
\text { by Question } \\
\text { Type }\end{array}$ & 33.17 & $3 \times 5$ & 512 & $\mathrm{P}$ & .05 \\
\hline
\end{tabular}




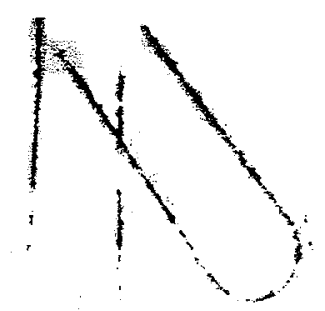

TABLE 3. A Comparison of Wr1tten and Cral Question Types

\begin{tabular}{|c|c|c|c|c|c|c|}
\hline & Recall & Application & Analysis & Synthesis & Evaluation & Total \\
\hline Oral & $\begin{array}{c}136 \\
(55 \%)\end{array}$ & $\begin{array}{c}35 \\
(14 \%)\end{array}$ & $\begin{array}{l}56 \\
(22 \%)\end{array}$ & $\begin{array}{c}10 \\
(4 \%)\end{array}$ & $\begin{array}{c}12 \\
(5 \%)\end{array}$ & $\begin{array}{c}249 \\
(100 \%)\end{array}$ \\
\hline Written & $\begin{array}{l}19 \\
(30 \%)\end{array}$ & $\begin{array}{l}19 \\
(30 \%)\end{array}$ & $\begin{array}{c}4 \\
(6 \%)\end{array}$ & $\begin{array}{c}18 \\
(29 \%)\end{array}$ & $\begin{array}{c}3 \\
(5 \%)\end{array}$ & $\begin{array}{c}63 \\
(100 \%)\end{array}$ \\
\hline TOTAL & $\begin{array}{c}155 \\
(50 \%)\end{array}$ & $\begin{array}{c}54 \\
(17 \%)\end{array}$ & $\begin{array}{c}60 \\
(19 \%)\end{array}$ & $\begin{array}{c}28 \\
(9 \%)\end{array}$ & $\begin{array}{c}15 \\
(5 \%)\end{array}$ & $\begin{array}{c}312 \\
(100 \%)\end{array}$ \\
\hline
\end{tabular}


stick - he self fulfilling prophecy'.
They present material which does not
challenge questions which scarcely
trouble the surface of the mind.
In creating questions for low stream
students (or any students), a teacher's
prime goal should be to stimulate thinking.
The level of reading materials and the
language of questions may vary to suit
the needs of the students. Advance
organizers should be used to integrate
new concepts into the students' existing
cognitive structures. It is our conten-
tion that higher order questioning is
appropriate and necessary at all levels.

The study also suggested that teachers tend to save many of their higher order questions for written work and ask more lower order questions when doing oral work. Such a practice might suggest a traditional approach of simple oral questions, directed at the class as a whole to establish a basic comprehension of the topic at hand before assigning a more complex written assignment. Yet such a practice risks producing students with sophisticated writing skills but relatively unskilled in thinking and reasoning orally.

If we are to avoid such dangers, then perhaps it is necessary to look at questioning methods that allow students a longer time to organize their thoughts and structure a response before answering, as well as teacher reactions that call for students to respond to and build on one another's answers.

Humanity has always been troubled by the constant change perceived in the environment; those best able to cope with the fact of mutability are those whose minds are able to go beyond the surface of things, to question, to evaluate and manipulate the sensory impressions received.10 Therefore, a teacher's questions need to lead to a questioning on the part of the students rather than a mere recapitulation symptomatic of blind acceptance. Since questions are a major part of classroom practice, it is not unreasonable to say that the graduate is in no small way a product of the teacher's questions. 
1. The research reported in this article is described more fully in, "An Investigation into the Questioning Techniques of Selected English Language Teachers in the Teaching of Comprehension in a Single New Providence Senior High School", unpublished B. Ed. Long Study, Nassau, 1982.

2. Gage, N. and Berliner, D., Educational Psychology, Rand McNally, 1975. p. 689 .

3. Floyd, w., (Quoted in Carin, A. and Sund, R., Developing Questioning Techniques, Charles E. Merrill, 1971, p. 44)

4. Gal1, (Quoted in Gage, N. and Berliner, D., op. cit. p. 695).

5. Guilford, J., General Psychology, Van Nostrand, 1952, p. 142.

6. Guzak (Quoted in Harris, A. and Sipay, E. How to Increase Reading Ability (6th Edition), U.S.A. 1978, p. 474).

7. Bartolme (Quoted in Harris, A. and Sipay, E. op. cit. p. 474).

8. Dunkin, M. and Biddle, B., The Study of Teaching, Holt, Rinehart and Winston, 1974.

9. The pre-selected passage was tested for its suitability for the grade levels, using Fry's reading difficulty scale.

10. Glinton, P., "Critical Reading" Trends, Vol. 1, No. 2, 1982. pp. 7-9. 